\title{
Artelogie
}

artelogie Recherche sur les arts, le patrimoine et la littérature de l'Amérique latine

10 | 2017

Après le paysage : l'art, l'inscription et la représentation de la nature en Amérique latine aujourd'hui

\section{Landscape and power: Taunay's and Burford's panoramas of Rio de Janeiro in Paris and London in the first half of the Nineteenth century}

Carla Hermann

\section{OpenEdition}

Electronic version

URL: http://journals.openedition.org/artelogie/796

DOI: $10.4000 /$ artelogie. 796

ISSN: 2115-6395

Publisher

Association ESCAL

Electronic reference

Carla Hermann, «Landscape and power: Taunay's and Burford's panoramas of Rio de Janeiro in Paris and London in the first half of the Nineteenth century », Artelogie [Online], 10 | 2017, Online since 05 April 2017, connection on 19 April 2019. URL : http://journals.openedition.org/artelogie/796 ; DOI : 10.4000/artelogie.796

This text was automatically generated on 19 April 2019

Association ESCAL 


\title{
Landscape and power: Taunay's and Burford's panoramas of Rio de Janeiro in Paris and London in the first half of the Nineteenth century
}

\author{
Carla Hermann
}

1 There were only two panorama paintings of the city of Rio de Janeiro exhibited in European rotundas in the first half of the nineteenth century. The first one, a cityscape originally drawn by Félix-Émile Taunay in 1822, exhibited in the Passage des Panoramas in Paris in 1824, is a view from the top of the Carioca Hill, a mountain considered to be the birth landmark of the town. The other Brazilian panorama was the product of Robert Burford, the owner of the Leicester Square rotunda in London. In June of 1827, a seascape of the Bay of Guanabara, the main entrance and port of the Rio, was shown in his venue, and remained open to the public for a little more than an year.

This paper aims to understand the agenda behind these representations. Since each represented an attitude of dominance over the faraway city of Rio, I compare and analyze the different choices made by the artists, as well as their marketing strategies and the political and economic motivations behind each one. It is significant that both cultural capitals made the option of showing Rio de Janeiro in the same decade.

My reading follows Robert Aguirre's notion of an informal empire, identifying Britain's expansionist politics towards cultural domination over countries that were not formally colonies of the British Empire, but lay in the British horizon of commercial and trading interests (AGUIRRE, 2005: xv). In this sense, the imperial influence was not formal or military; rather, this dominance usually came in the disguise of art, travelling narratives and accounts, captured during expeditions and turned into collections in London. We can identify a range of material culture produced specifically within this context, which aimed to inform people "at home" of what existed in the world outside Britain. Throughout the long nineteenth century, scientific discourse helped building images of 
otherness, crafting ideas about different races, geographical determinism and territorial conquests. All in order to make the uneven dominance to appear as natural to the eyes of those who lived in the cultural and economic capitals. This discourse relates to the panoramas and natural exhibitions as they "treated the world as an identifiable array of objects to be collected or painted and visually possessed as knowledge" (OLEKSIJCZUK, 2011: 60) and helped to build the images of other places and people.

4 Although both London and Paris believed themselves to be world capitals in the early nineteenth century, it is important to mention that the panorama as a medium was a British invention. More precisely, Robert Barker, an Irish born painter based in Edinburgh, received the patent for this invention in the year of 1787 . In the following year, Barker managed to be successful showing a view of Edinburgh and its environs. The exhibition was indeed a novelty for Edinburgh city life, and it was most obvious for Barker to take it to London, where full-scale and regular public exhibitions of contemporary paintings were regular activities since the 1760s. London had many people willing to consume new urban spectacles due to the rapid economic growth brought by the industrial revolution.

Once in the British capital, Barker had to face the competition of different attractions. For example, the Eidophusikon was a large-scale miniature theater in which, with transparent moving canvas and models, it was possible to provide different lights for the scenes, recreating day and night hours, as well as weather changes. The use of colored glass filters increased the illusion on reality. Other competition included cork models with miniature replicas of buildings and cityscapes, the Royal Academy annual show, natural museums and art exhibitions. In order to sell his work to the public, Barker would stress that the panorama did not bear the need for any kind of "deception", such as distorting or colored glasses. Denise Olekijczuk quotes a passage from an advertisement in which Barker says: "The idea is entirely new, and the effect, produced by fair perspective, a proper point of view, and unlimiting the bounds of the Art of Painting" (OLEKSIJCZUK, 2011: 51). It is clear that Barker situates his work inside an artistic discussion. Believing that his invention is indeed a way of improving the art of painting, he mentions of the use of "fair perspective" to tell us that all the tricks employed to deceive the eye were achieved with sketches and painting, and did not depend on external apparatus for the spectators.

6 From the understanding of Barker's proposal, we can assume that the panoramas uniqueness is the fact that they relied on painting and painting only to create illusions. It is true that in the second half of the nineteenth century the panoramas would use tridimensional objects to build the faux terrain, a resource meant to approximate the visiting public to the image, and make a soft transition from their own bodies to the plain surface of the view. However, these early panoramas, such as the ones mentioned in this text, were entirely related to painting.

7 The novelty of the panorama was to apply the perspective to a curved canvas, enabling to set the representation free from the boundaries of the frames. The way of exhibiting it, providing an immersive and surrounding experience, has also led to its success. Ultimately, the shape and size of these images were factors that made the panoramas so different from the rest of the competition. The two-story rotunda that Barker erected in Leicester Square in 1793 could accommodate canvas larger than "10000 square feet" (OETTERMANN, 1997: 105). The architectural concept of the tailor-made room provided the viewers the experience of being surrounded by an actual landscape, as they entered 
the space through an underground dark corridor and emerged in the middle of the huge painting. This was the very same building where the Rio de Janeiro was presented over thirty years later.

Robert Mitchell, Section of the Rotunda, 1801

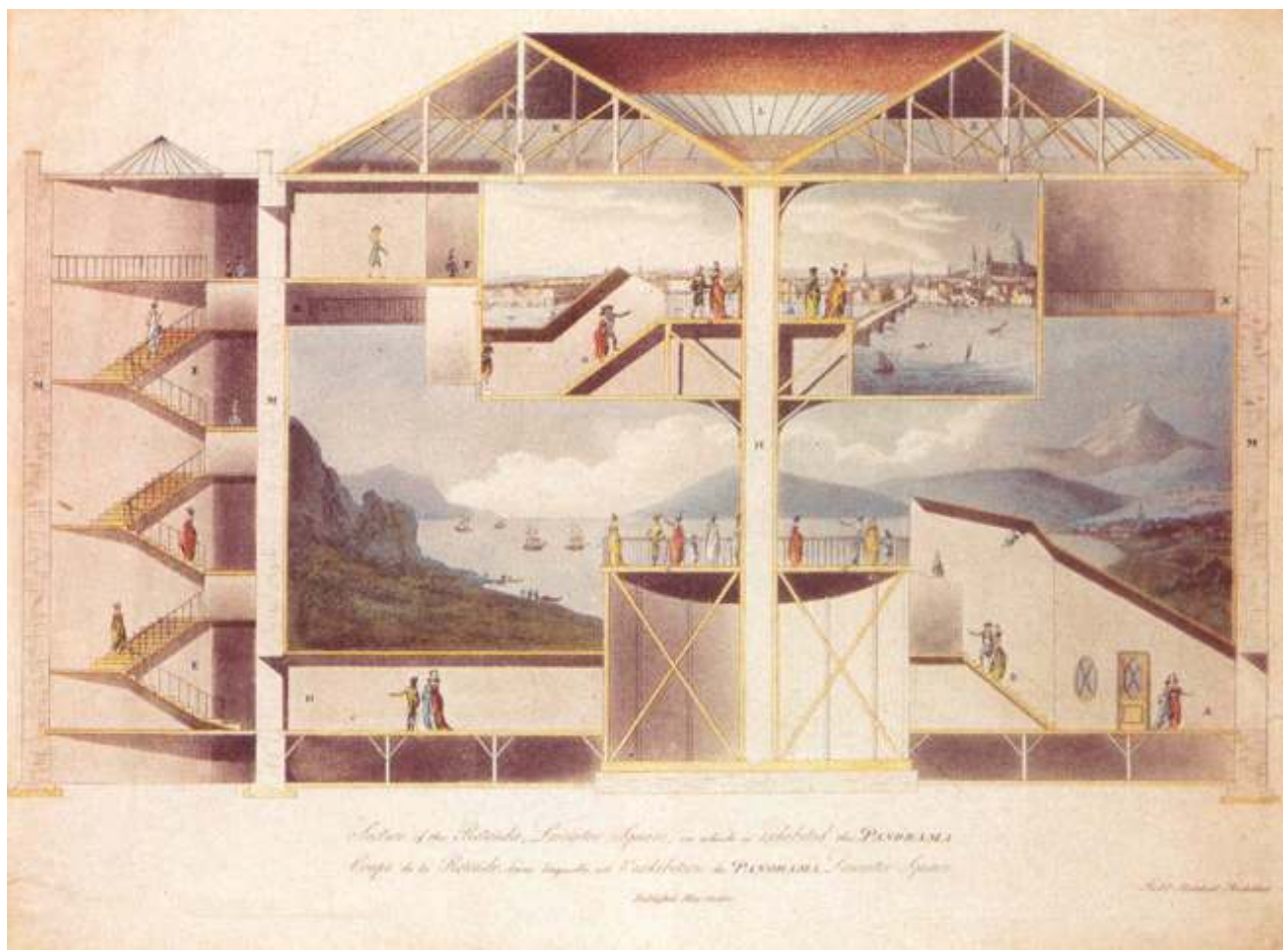

Leicester Square, colored aquatint, $11.2 \times 17,5$ inches

Barker would remain as the only panorama owner until the expiration of his exclusiveness patent in 1801. After that, other rival panoramas appeared in London (HYDE, 1988: 20). However, panoramas were produced in France before the expiration of the patent. His early works toured the major cities of the United Kingdom and continental Europe, until they began to fall to pieces. It became obvious that there was a promising market to explore in this genre of entertainment. In 1799, American engineer Robert Fulton made an agreement with Barker for a ten-year license (COMMENT, 1999: 29). In the summer of that year he erected a rotunda in the Jardin des Capucines in Paris with a view from Paris made by Pierre Prévost, a painter who would later become owner of his own rotunda. Unable to proceed in his enterprise, Fulton sold his patent to James Thayer, another American entrepreneur, who manage to erect in the flowing years two buildings for panoramas in the Boulevard Montmartre (HYDE, 1988: 20). In 1808 Thayer and Prévost joined forces and opened a rotunda at the corner of Boulevard des Capucines and rue Neuve-St-Augustin. This was the venue where the Parisians would see Rio de Janeiro years later.

It is noticeable that in both cases the decision to show such views was not only determined by the large-scale economic and political issues. It was also related to their owners desires. These men were able to understand what the public wanted to see, and how much people were willing to pay for it. To analyze the panorama phenomenon within the notion of cultural consumption, we have to consider the role of the proprietors, - sometimes more of businessmen than artists themselves. 
10 Now it is time to look at each work individually. We shall start with the British panorama of Rio de Janeiro. Description of a view of the city of St. Sebastian and the bay of Rio de Janeiro is named after the title of the brochure that accompanied its exhibition in 1827. It contained a brief history of Brazil and an explanatory key, which marked the landscape with a descriptive list of its elements. This printed image is the only testimony of the view, since the original painted canvas was lost, like every other Burford's works.

Description of a view of the city of St. Sebastian, and the Bay of Rio Janeiro: now exhibiting in the Panorama, Leicester-Square.

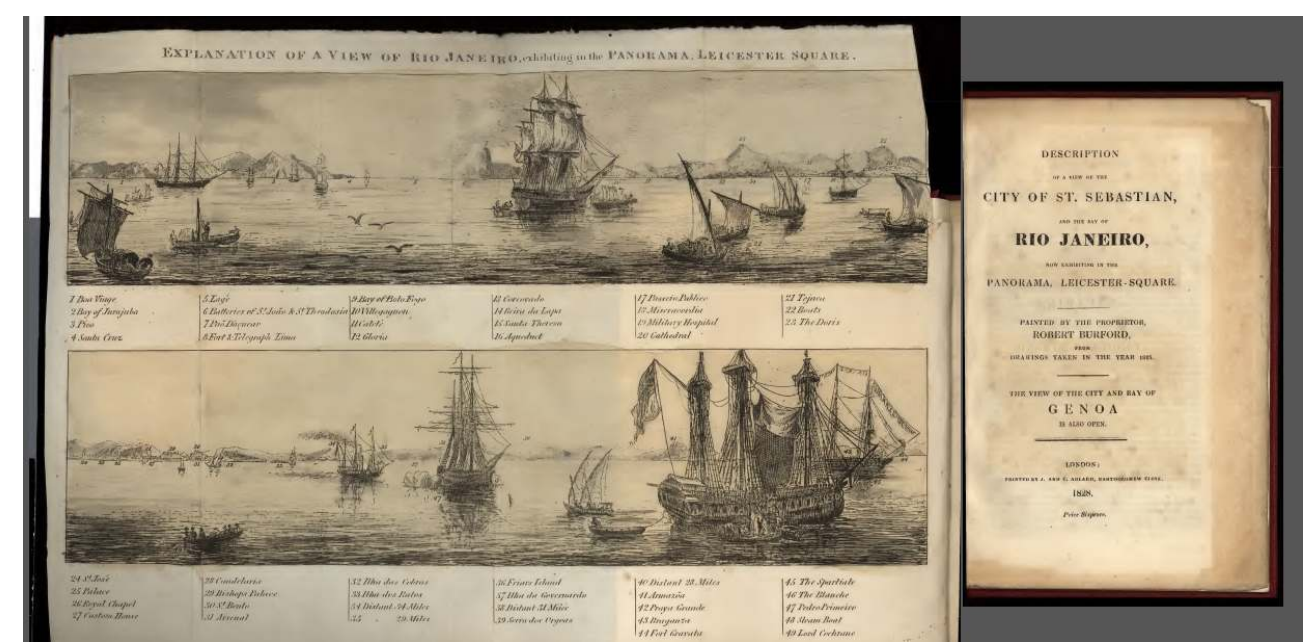

Painted by the proprietor, Robert Burford, from drawings taken in the year 1823, 1828. Printed by $\mathrm{J}$. and C. Adlard, London.

Source: The Getty Research Portal

11 The composition of the image, divided in two even horizontal parts, follows a common structure in Burford's panoramic views. The key intended to facilitate the recognition of the main elements in the vista, and people could read the names and identify their corresponding images in print. In addition, these printed keys guaranteed the circulation of these landscapes for a wider public, and sometimes were collected, traded and given away as gifts.

In this specific case of Rio, half of what we see is water, and the other half is land. This division enhances the actual geographic distance. The physiognomy aspects of the Sugar Loaf and Corcovado mountains, the most important landmarks of the city, appear in the background, in less favored scale. The organization of the composition is clearly divided into two planes and has the purpose of marking the distance between the city and the vessels in the Bay. The trick makes the city seems sometimes distant - as if we had to run through halfway of the composition to get to it - and sometimes close enough, because its existence is mediated through the presence of the big vessels in front of it.

The print landscape came inside a sixpence booklet, with a twelve-page text with historical and spatial information. This text also provides a clue on the image of the city. It describes Rio as the "metropolis of all Brazil", due to the proximity to mining areas (such as the state of Minas Gerais and the Plate River in the South portion of the country) and the spacious and safe harbor of Rio. In fact, the harbor has a leading role in the description of the city. The text praises the perfect location - "perhaps no port in the whole world is better situated for general trade: it enjoys the convenience of intercourse equally with Europe, America, Africa, the East Indies, and the South Sea Islands; and, as 
the capital of a rich and most extensive country, commands internal resources of immense amount and value" (DESCRIPTION, 1828: 3). It follows a description full of compliments, for its capacity and safety for the vessels of every shape. "The entrance, embosomed in lofty and sublime scenery, is only 850 fathoms in width and 14 deep. It is at all times easy of entrance and egress". Surrounding nature, richly described, includes the granite rocks, the dark green of the tropical plants and their contrast with the pale sand of the beaches and the blue sea, with the background of mango and orange plantations. The naturalistic description full of picturesque aspects aims to approximate the pamphlet narrative to travel writing. The purpose of the description of landscape, an essential feature of British (formal and informal) imperialism, was to inform and situate the reader inside the described landscape, giving him or her an idea of total experience. At the same time, as Mary Louise Pratt claims, it gave the reader notions of order and the world as a system, and was a way of justifying imperial thinking and its dominance (PRATT, 2003: 29).

the booklet, the text is full of the word "picturesque" as an adjective, just like in travel writing, where the author calls the attention of the reader towards different and curious things. Here it is used do describe the constant presence of international ships in the bay under the bright and cloudless sky. It employs "picturesque" to qualify a sort of positive cosmopolitanism for Rio, and the harbor is central in this construction, since it is the place where trade happened and is the entrance to the city. The text tells us about the existing goods and merchants in the city, as well as its architecture, and presents a scenario of Rio as a very pleasant place to be. More than a presentation or a visiting card, this panorama is a propaganda selling a modern and neat place. Along with the image, the printed guide directs our gaze in linear way. Everything that must be seen is beyond the line of vessels, and the background shows itself as something to be discovered.

We can work with the idea of informal imperialism for the Brazilian vista and the indirect influence of Britain over Brazilian naval power. We can consult The First Panoramas: Visions of British imperialism, a 2011 book from the already mentioned author Denise Oleksijczuk for a efficient material for the relationship between this media and the demonstration of power. It analyzes the formal and material aspects of the Barker panoramas, relating this art form to the diffusion of the British imperialism. The rotundas and explanatory keys were responsible for the emergence of a new public eager to consume global and international images related to the position of the United Kingdom within the whole world. Indeed, during the years of the French Revolution (1793-1802), half of the scenes in the canvases of the Leicester Square rotunda depicted British fleets. And in the years of the Napoleonic Wars (1803-1815) almost every image was related to me movements of the Royal Navy or the British Army. More than an entrepreneur's initiative attempting to create a taste for war and battle images, this was an actual trend, and the public responded accordingly, attending in mass to these panorama shows. Oleksijczuk gives us the numbers: the check of Robert and Henry Aston Barker bank accounts indicates that during the Peninsular War (1808-1814) the number of patrons of the panoramas raised from forty to sixty thousand annually. Even more significantly, in 1816, when the Battle of Waterloo painting was displayed, one year after the actual conflict, this rate raised up to two hundred thousand visitors in only one year. (OLEKSIJCZUK, 2011: 7)

16 Just like Pratt affirmation that the natural order of the world was a way of justifying dominance, the imagery construction of the Empire worked towards naturalizing its unfair and unequal actions. It was necessary to show massacres as conquest, wars as 
heroic acts and to disguise the commercial interests as civilizatory actions in the colonized and exploited colonies and foreign lands. The panorama rotundas worked as perfect places for this kind of construction, due to their popularity and because they were accessible places for different social classes in London. Moreover, as the years passed, they would also show places that represented targets for these informal interests of the British Empire.

So, if in the Brazilian view the composition seems to describe the landscape with ideological neutrality, the representation of three British Royal Navy vessels in the bay denotes an attempt of dominance in disguise. Instead of a coastal scene simply showing the natural and cultural aspects of the city, Burford decided for a landscape inhabited of ships. They are scattered all over the water, in different sizes and shapes. We see small boats with fishermen and their nets, another boat with a sheet full of wind, boats with men loading goods in bigger ships, a steamboat in the move, trembling the calm Guanabara Bay waters. They symbolize the dynamic commercial relationship of trading and commerce that was usual at that time. The big vessels are the protagonists in the painting. They are even bigger than the mountains in the background. The highlights are the main Brazilian frigate Pedro-Primeiro, and two British ships: HMS Doris and Blanche. This last is the largest single feature in the panorama, and such were the efforts to make it appears as realistic as possible that the printed commentaries praised about how detailed and vivid the ship felt, with defined figures and accurate movements of people. A paper said " $[. .$.$] strikes on our entry, and so powerful is the effect, that we could scarcely$

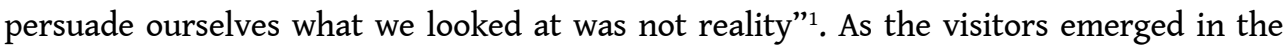
center of the rotunda, they faced first the presence of the British Navy in Rio, and only after they would see the city in the coast, that acted as a background for the bay. Furthermore, one of the smaller boats brought the figure of Lord Cochrane, a controversial and popular British official, who was expelled from the Royal Navy. Cochrane was hired Commander for the Brazilian Imperial fleet by Emperor Pedro Primeiro in 1823, and became a Brazil national hero, after two successful campaigns in the same year, after combating resistant and anti-independence forces in Bahia and Maranhão. Lord Cochrane figure in the panorama was essential to create empathy for the London public and also to reinforce that the new Brazilian Empire needed England for trade and had to consider it an ally. The message is clear: the city that was once a colonial mystery, protected by the Portuguese from any foreign visitors, is now a new and young Empire, and it was open to world, with England's help.

The British presence, however, was also felt throughout the textual description of the city of Rio de Janeiro. In a manner of telling that the United Kingdom was already present in Brazil and turning the unknown view more accessible to the public in London, it says:

London superfine' meets the eye in every quarter; cottons and cloths from Manchester and Yorkshire, Hardware from Birmingham, crockery, \&c. are but little dearer than in England. There are also many houses for the sale of eatable and liquors, kept by Englishmen, who, as a temptation to their countrymen, have hoisted their favorite signs of Union Jacks, Jolly Tars, Red Lions, \&c. (DESCRIPTION, 1828: 7)

The vista from the water puts the viewer in the condition of someone inside a ship arriving at the city. Additionally, the Leicester Square rotunda was London most important entertainment venue, and London was already considered to be one of the capitals of the world. So, one could feel at the center of the modern world and visit, from there, the rest of the world. After all, when one entered the rotunda, one emerged 
literally, in the center of a different foreign land. To place the spectator as a traveler is one of the most important characteristics of the rotunda panoramic phenomenon. Its capacity to emulate different and faraway places put the panoramas in the position of "travel replacements", and allowed thousands of Londoners to "go" places without ever leaving their hometown. This was also valid for other panoramas scattered around other European cities.

Felix-Émile Taunay, Panorama do Rio de Janeiro, 1822.

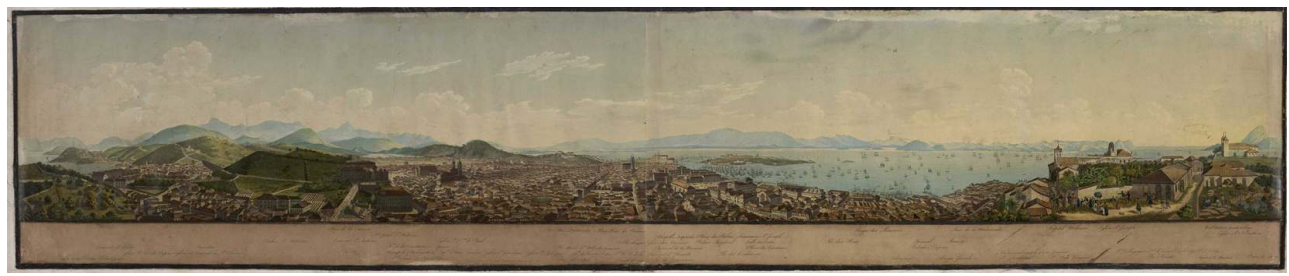

$17 \times 102 \mathrm{~cm}$, hand colored acquatint, Brazilian National Library.

Much of our contemporary estrangement towards a representation of Rio from its waters instead of the city comes from the comparison with another, better known, panorama: Taunay's. Unlike Burford's, the French panorama presents a very urban Rio de Janeiro from the city and facing the bay. Entitled simply as Panorama do Rio de Janeiro, it was based on drawings of Felix-Émile Taunay, a French born academic landscape painter living in Brazil in 1822. It opened in the most significant panorama venue in Paris in May 1824 and transported the visitors to experience a taste of Brazil.

21 The choice of the Castelo Hill had a symbolic importance: it was considered to be the place where the city first grew as an urban site, in the $16^{\text {th }}$ century. The elevated position of the center of the rotunda resembled the elevated position from the top of the hill. The perspective is built on this condition of placing the viewer on the top from where they could see all the urban growth that had taken the colonial site. For that, the waters of the Bay appear as the horizon, and it is gradually brought closer to the eyes with the mediation of the city that exists between them. The town lies inside nature - it is placed between the mountain and the sea. And as nature and city come together, houses are confounded with the mountain slopes. Mountain, fields and plants become one with the built environment and are the half bottom of the panorama, while the skies fill the upper half of the horizon.

Along with the efforts of natural details, the painters were worried with the accuracy of the urban plan and the topographical precision, to show something of a spirit of the city of Rio, and the life that ran through its streets. In the highly detailed painting, it was possible to distinguish streets, people walking and passing by, architectural details and many other specific aspects.

Although densely populated, it is possible to discriminate the main from the secondary streets, the color of the rooftops, the typically Portuguese white walls with wooden windows. The colonial constructions are about to be signified in a city with a hint of neoclassical spatial order, with signs that the modernity had already arrived in the tropics. We see the fountain and the aqueduct. We see slaves working and carrying things around, and the movement in carriages and horses. There are squares and free spaces. And although they are not the focus of the composition, we see an enormous number of ships and boats in the Guanabara Bay - maybe this could complement Burford's drawing. 

A see the Emperor of Brazil, Don Pedro I and his entourage. The text also highlights his specific scene. This scene is a record of the recently proclaimed Independence, one year prior to the making of this panorama. This fabricated empirical evidence is the key to understand the motivation behind this panorama. The description o the scene presents: "The Emperor, the Empress and Prime-Minister José Bonifácio in national guard uniform, which he commands. This confirms the new principles that reign in the country" (TAUNAY \& DÉNIS, 1824: 286). The principles the text refers to are the liberal ones. The international politic scenario for Brazil was fragile at that moment, since Portugal still hold absolutist aspirations and took more than two years to recognize its Independence in 1822. Having a hard time to be recognized as a new State, Pedro I was aware of the power that the presence in the French capital would bring to Brazil. In November of 1823 the diplomat Domingos Borges de Barros was nominated to work along with Louis XVIII court, in order to promote Brazilian imagery in the periodicals and to convince French public opinion in the favor of Brazil. One of his many efforts resulted in the panorama, which he later admitted in a letter that "had more effect than any book description ever published" (MARTINS, 2012: 37). By 1824, the year that Taunay's view opened to the public, the news of the difficulties caused by Brazil's intern political turmoil and the lack the Portuguese recognition were all over the most important European newspapers. However, when the French press covered the opening of the Brazilian panorama, the notice of a renovated country was once more publicly exposed. Perhaps the portrait of Rio de Janeiro as the capital of the New Empire, with its tropical colors and cosmopolitan vocation helped to build a better image for Brazil. As a coincidence (or not) Portugal finally accepted the independence in 1825.

Taunay's canvas, just like Burford's, is nowhere to be found. Being ephemeral exhibition works, these panoramic paintings were not built to last. They were even sometimes recycled, and had other panoramic views painted over. All we know about them comes from newspapers, keys and pamphlets, and in the case of the French one, from posterior series of engravings. Such was its success that high quality aquatints were sold as souvenirs in the following years. This gives us a glimpse of the role played by Paris in London regarding the dissemination of an image of the city of Rio to the world.

Needless to say that the French panorama does not acknowledge the influence of a British informal Empire, it is related to another strategy of propaganda. It is a self thought image of a young and fragile Empire from a former colony in South America seeking for support 
and recognition. Despite having proclaimed itself as an Empire, Brazil was simply not seem as a powerful international authority like the French and British Empire saw each other. However different the economic or political benefits in each case were, both illustrate how the panorama medium was a powerful image builder. In the Parisian rotunda, the painting of Rio was proceeded chronologically by panoramas of Wagram, Calais, Antwerp, London, Florence, Jerusalem and Athens. The Burford rotunda in Leicester Square showed Rio after Pompeii, Mexico City, Madrid and Geneva, amongst others (PEREIRA, 2006: 146). The fact is that when exhibited among such a diverse group of cities, Rio de Janeiro appeared to be open to contact with the outside world and to participating in the new industrial liberalism.

Finally, it is necessary to make a last spatial remark that puts both London and Paris in similar position regarding these readings of Rio and other cities promoted through the panoramic exhibitions. As Aguirre observes, the relationship between center and periphery in the imperialist world order division is reproduced within the round walls of the panorama building. The privileged position of the individual in the platform instigates a sense of ownership, as the vision dominates everything before the eyes. And with the subjects of faraway places "brought" to London or Paris, it also put the spectator in the center of the civilized world. From the panorama balcony, they could know other places without ever leaving home, and had the idea that the Empire - just like the circular canvas - had no boundaries.

\section{BIBLIOGRAPHY}

COMMENT Bernard, The Panorama, London, Reaktion Books, 1999.

Description of a view of the city of St. Sebastian, and the Bay of Rio Janeiro: now exhibiting in the Panorama, Leicester-Square; painted by the proprietor, Robert Burford, from drawings taken in the year 1823, London, Printed by J. and C. Adlard, 1828. Evening Mail. June $25^{\text {th }}, 1827$.

HYDE Ralph, Panoramania!, London, Trefoil in association with Barbican Art Gallery, 1988.

MARTINS Carlos, "Rio de Janeiro, Singular Paisagem", in Panoramas - a paisagem brasileira no acervo do Instituto Moreira Salles, Julia KovENSKY (org.), Rio de Janeiro: Instituto Moreira Salles, 2012

OETTERMAN Stephan, The Panorama: History of a Mass Medium. New York, Zone Books, 1997. OLEKSIJCZUK Denise, The First Panoramas: Visions of British Imperialism, University of Minnesota Press, 2011.

PRATT Mary Louise, Imperial Eyes: Travel Writing and Transculturation, New York, Routledge, 2003.

PEREIRA Margareth da Silva, "O olhar panorâmico: a construção da cidade como experiência e objeto do conhecimento (1800-1830)", in RUA - Revista de Urbanismo e Arquitetura, vol. 7, n6, Salvador, UFBA, 2006

TAUNAY Hippolyte, DÉNIS Ferdinand, Notice historique et explicative du panorama de Rio Janeiro, Paris, Editions Nepveu, 1824. 


\section{NOTES}

1. Public Ledger and Daily Advertiser. 06/23/1827.

\section{ABSTRACTS}

There were only two panorama paintings of Rio de Janeiro exhibited in European rotundas in the first half of the Nineteenth Century. They were a view from the Bay of Guanabara displayed by Robert Burford in London's Leicester Square rotunda in 1827 and a view from the top of the Carioca Hill, originally drawn by Félix-Émile Taunay in 1822 and exhibited in the Passage des Panoramas in Paris in 1824. The paper aims to understand the agenda behind the representations on the two sights. Because they both represented manners of dominance over the faraway city of Rio, I compare and analyze the different choices made by the artists as well as their marketing strategies, and the political and economic motivations behind each one.

Il n'y avait deux peintures panoramiques de Rio de Janeiro exposées dans rotondes européennes dans la première moitié du XIXe siècle. Ils étaient une vue de la baie de Guanabara affichée par Robert Burford dans londonien Leicester Square rotonde en 1827 et une vue du haut de la colline Carioca, dessinée par Félix-Émile Taunay en 1822 et exposé dans le passage des Panoramas dans Paris en 1824. Cette document vise à comprendre les idées derrière les représentations sur les deux sites. Parce que ils représentent differente manières de domination sur la ville lointaine de Rio, je compare et analyse les différents choix faits par les artistes ainsi que leurs stratégies de marketing, et les motivations politiques et économiques derrière les images.

\section{INDEX}

Mots-clés: panoramas, paysage, XIXe siècle, impérialisme informel, Rio de Janeiro, Paris, Londres

Keywords: panoramas, landscape, nineteenth century, informal emperialism, Rio de Janeiro, Paris, London

\section{AUTHOR}

\section{CARLA HERMANN}

PhD, Universidade do Estado do Rio de Janeiro carla.hermann[at]gmail.com 